ISSN 2078-6441. Вісник Львівського університету. Серія географічна. 2014. Випуск 47. С. 124-135. Visnyk of the Lviv University. Series Geography. 2014. Issue 47. P. 124-135.

631.445 (477)

\author{
икол інчук 1 их йло евчук ${ }^{2}$, етро іньчук ${ }^{2}$ \\ 1 олинськ філія “нститут охорони грунтів кр їни”, \\ вул. лушець, 49, 43010, м. уцьк, кр їн \\ 2 хідноєвропейський н ціон льний університет імені есі кр їнки, \\ вул. от пов , 9, 43021, м. уцьк, кр їн
}

орушено пит ння лок льних невідповідностей ре льного грунтового покриву теоретичним д ним. днією з причин невідповідностей є ігнорув ння проблеми особливостей регіон льних грунтових відмін. ро н лізов но ситу цію в підход х суч сної кл сифік ції грунтів в кр їні, близькому з рубіжжі т н міжн родному рівні. иявлено ктивний розвиток кл сифік ційних моделей у східноєвропейських кр їн х. кцентов но ув гу н перспективі розвитку п р метричних підходів у кл сифік ції грунтів кр їни. пропонов но методику регіон льної г рмоніз ції грунтового покриву олинської обл. з вдяки ідентифік ції перев жних типів грунтів у суч сних кл сифік ціях т іжн родній рефер тивній 6 зі грунтових ресурсів. екомендов но проводити періодичний моніторинг ст ну кл сифік ційного н пряму грунтів 3 метою регіон льної г рмоніз ції критеріїв ді гностув ння грунтових відмін, ктивіз ції діяльності місцевих грунтозн вчих осередків для оцінки рівнів узгодженості н укових розробок у кл сифік ції т удоскон лення норм тивної б зи грунтових ресурсів кр їни.

лючові слов : грунти, кл сифік ції генетичні, кл сифік ції п р метричні, т ксони, грунтотворні процеси,

еликом сшт бне грунтове обстеження кр їни й територій союзних республік колишнього , як відомо, проведено н поч тку 60-х років ст. я величезн 3 м сшт б ми т змістом робот з кл л фунд мент льні підв лини для р ціон льного використ ння в господ рстві земель н 3 с д х принципів якісної т кількісної оцінки грунтів. ей проект ре лізув ли зусиллями сотень н уковців $\mathrm{T}$ сотень тисяч грунтозн вців, які були підготовлені в досить короткий період з дост тньо спрощеною методикою тодішньої московської школи грунтозн вців.

всіх позитивних скл дових проведеного грунтового обстеження з огляду н методичні, економічні т суб'єктивно-ф хові причини проігноров но регіон льні особливості зн чної ч стини грунтових відмін, які було в жко ідентифікув ти згідно з визн ченою прогр мою. зн чимо, що вн слідок цих причин грунтовий покрив деяких природних зон н десятки років “змінюв в” свій регіон поширення. к прикл д, зг д ємо бурі лісові грунти ередк рп ття, які до середини 80-х років ув ж ли дерново-підзолистими. рім того, імовірно, що в нед лекому м йбутньому дерновопідзолисті грунти олісся, як зон льні, поступляться дерновим опідзоленим. будьякому р зі (з вл сним досвідом) у регіоні хідного олісся кр їни це м є ре льні природно-морфологічні т кл сифік ційні (п р метричні) підст ви.

(C) інчук ., евчук ., іньчук ., 2014 
втор ідеї п р метричної генетико-еколого-субст нтивної кл сифік ції [6] стверджує, що невідповідність н явного грунтового обстеження дод тковим коригув льним дослідженням сьогодні ст новить до $50 \%$.

н шу думку, у більшості вип дків ця невідповідність зумовлен недооцінкою ролі лок льних т регіон льних особливостей грунтового покриву, що призводить до 3 кономірного помилкового з числення низки грунтових відмін у іншу кл сифік ційну к тегорію. рім того, нем розвинутих лок льних (територі льних) грунтозн вчих шкіл, дже підготовку ф хівців сьогодні ведуть н рівні з г льного грунтозн вств . окуч $є$ в т . околовського. ит ння ж кореляції н віть морфологічних п р метрів у деяких регіон льних грунтових відмін $є$ неоднозн чним.

вернемо ув гу н не бияку ктивність щодо розробки кл сифік цій, з звич й, $з$ одиницями вищого р нгу н терен х кр їн колишнього, , н м г ння з стосув ти в н ціон льній грунтозн вчій н уці міжн родні ст нд рти. е ж прит м нне й укр їнському н ціон льному грунтозн вству. одноч с пит ння г рмоніз ції регіон льних особливостей грунтового покриву досі не вирішене.

огляду н ці причини н фоні тенденцій глоб ліз ції в кл сифік ції грунтів невирішен проблем ді гностув ння місцевих особливостей грунтового покриву т його кл сифік ційної ідентифік ції приведе до под льшої плут нини, викривлення інформ ції щодо ре льного ст ну грунтового покриву т втр ти зн чення грунтозн вчої н уки і пр ктики для місцевого гр рного бізнесу, відповідно - держ ви з г лом.

ля 3 побіг ння можливим нег тивним н слідк м необхідною умовою $є$ періодичний моніторинг ст ну системи кл сифік ції грунтів як у вертик льному (від міжн родних принципів до лок льних ді гностичних критеріїв грунтових відмін), т к і в горизонт льному н прям х ( н ліз розвитку кл сифік цій в кр їні т держ в х перспективної співпр ці).

ур хув нням високої неоднорідності грунтового покриву олинської обл., н пр цьов ного лок льного польового дослідного м тері лу, уз г льненого досвіду в колективній моногр фії [1] т відповідній к рті грунтів [3] ми уз г льнили суч сний ст н кл сифік ції грунтів в кр їні, осії, ілорусі, про н лізув ли провідні міжн родні підходи з метою чіткого визн чення місця регіон льних типів грунтових відмін олині у цій системі, як , імовірно, інтегрув тиметься. к в жливу пр ктичну скл дову уточнено ді гностичні критерії 3 пріоритетними н прям ми суч сних кл сифік ційних підходів.

жливим інструментом інтегр ції кл сифік цій слугують підходи, прийняті для

іжн родної рефер тивної б зи грунтових ресурсів (The World Reference Base for soil Resourse (WRB), 1998) [8], як побудов н н підст ві провідних н ціон льних кл сифік цій 3 морфогенетичним принципом - генетичними горизонт ми т вл стивостями, і об'єднує великі грунтові групи н рівні генер ліз ції типу. широкому розумінні в цій системі грунти об'єдн ні з скл дом (орг ногенні т мінер льні) $\mathrm{T}$ зумовленими чинник ми впливу $\mathrm{H}$ формув ння профілю ( нтропогенним, клім тичним, топогр фічним (рельєфу), м теринської породи). кий підхід д є змогу гнучко розвив ти н ціон льні кл сифік ції н нижчих т ксономічних рівнях з ур хув нням особливостей кр їн і не є кл сифік цією в прямому розумінні. е рефер тивн 63 з елемент ми ієр рхічної структури т форм льними меж ми кл сів. ї головне призн чення - кореляція н ціон льних грунтових кл сифік цій, тобто ре ліз ція глоб льної уніфік ції зн нь про грунтові ресурси. 
ит ння кл сифік ції грунтів кту льне в усіх кр їн х 3 ктивною економікою, оскільки воно є пр ктичною, ч сто й з конод вчою основою продовольчої безпеки. думку . піш зі спів вт. [4], відомі дв способи вирішення кл сифік ційної проблеми грунтозн вств :

1) створення “універс льної” кл сифік ції грунтів, прид тної для комплексного використ ння в різних г лузях н уки й особливо в пр ктиці через в рі нти “н ближень", з періодичним удоскон ленням їх новими д ними і можливостями теоретичного й прикл дного грунтозн вств . їхній основі $є$ субст нтивний підхід до систем тики грунтів, з требув ний пр ктикою. кремі 3 цих кл сифік цій можн розгляд ти як модернізов ний в рі нт (симбіоз) ф кторно-генетичної і субст нтивногенетичної кл сифік цій;

2) ур хув ння скл дності й неоднозн чності універс льного в рі нт кл сифік ції грунтів для одноч сного й ефективного вирішення н укових т пр ктичних з вд нь, що ре лізують через різні кл сифік ції - для н укового і виробничого використ ння окремо.

ринципи першого способу ре лізують у систем тиці й кл сифік ції грунтів .

їхню основу взято систему “сьомого н ближення", як повною мірою відобр ж $є$ кл сифік ційну проблему грунтозн вств , що ніколи не буде ост точно вирішеною, проте з вжди є в жливою і пріоритетною.

осить спрощеною є структур європейських кл сифік цій грунтів. ї ре лізують ч стково $з$ другим н прямом, оскільки вон грунтується н підход х пр ктичного землекористув ння.

н чно б г тогр нніші східноєвропейські слов'янські кл сифік ції, які продукують різні н прями кл сифік ційних в рі цій, нез нг жов ні суто пр ктичними з вд ннями, тому є досить фунд мент льними, проте ч сто громіздкими т суперечливими. ме ця особливість спонук $є$ до постійного н лізув ння отрим ної інформ ції т проведення коригув льних з ходів з метою виявлення місця регіон льних типів грунтів у дин мічній кл сифік ційній системі. ому розглянемо їх дет льніше.

уч сний розвиток кл сифік цій н постр дянських терен х грунтується н генетичному підході, ре лізов ному в пр ці “ л ссифик ция и ди гностик почв

" (1977). рівні типу і т ксонів його збережено в нових кл сифік ціях грунтів осії т ілорусі $[12,9]$. роте в господ рську пр ктику введено нові н дтипові т ксономічні групи - відділи, кл си і підкл си у ілорусі т відділ, стовбур (ствол) у осії. они досить чітко корелюють з WRB. дтипові рівні відобр ж ють особливості еволюції грунтового покриву н тлі нтропогенного чинник т збіжність будови профілю в р зі відповідного співвідношення перев жних чинників грунтоутворення

ме цим способом розвив ється і кл сифік ція грунтів “ ьоме н ближення”.

кр їні кл сифік ційн проблем грунтів перебув є н ст дії концепту льного обговорення, суть якого можн звести до б ж ння м ксим льно зберегти б г торічну грунтову інформ цію в р мк х нової кл сифік ції, побудов ної н 3 с д х нових підходів до кл сифік ції грунтів, що д сть змогу сповн використ ти н бутий досвід т вр хув ти н ціон льні пріоритети.

вітчизняній грунтозн вчій н уці н йбільш грунтовними $є$ н прями генетичної ( . ихоненко) т генетично-еколого-субст нтивної кл сифік цій. руг , 3 пропонов н . олуп ном [6, 7], грунтується н принцип х зон льності, генетичності, ієр рхічності, субст нтивності, сп дкоємності т розумної доцільності. ї особливістю $є$ збереження б зових фунд мент льних принципів i методів 
грунтозн вств в кр їні, проте вон ч стково нівелює недоліки кл сичного описового методу вн слідок з стосув ння субст нтивно-п р метричних критеріїв (коефіцієнт профільного н гром дження гумусу ( ) т коефіцієнт відносної кумуляції гумусу ( )). я кл сифік ція містить т кі т ксономічні одиниці: тип - підтип рід - вид - в рі нт - літологічн серія. Йнижчий т ксономічний рівень (літологічн серія) конструктивно корелює зі стовбур ми російської кл сифік ції (постлітогенний, синлітогенний), які, відповідно, є вищими (н дтиповими) груп ми. цьому р зі однозн чно зрозуміл протилежність підходів до побудови ієр рхії кл сифік ційних рівнів, проте це повністю з довольняє принципи WRB щодо н ціон льних кл сифік цій.

зн чимо про неоднозн чність думок стосовно цієї кл сифік ції, оскільки вон , як і всі інші, містить певні ксіом тичні елементи, що з слуговують н критику ( ихоненко, 2005; нівець, 2007). роте ця робот є в жливою скл довою процесу формув ння н ціон льної кл сифік ції грунтів кр їни.

енетичн кл сифік ція грунтів кр їни об'єднує т кі кл сифік ційні одиниці: ц рство грунтів - відділи - соці ції - сім’я грунтів - тип - підтип - рід - вид відмін - розряд. ній відобр жено суч сні тенденції до розвитку “н дтипових" рівнів т певною мірою тенденцію до інтегр ції з WRB, як систем тизує досить об’ємні т не з вжди однозн чні х р ктеристики грунтів.

к окремий вип док, в укр їнській грунтозн вчій н уці треб розгляд ти підхід до кл сифік ції гідроморфних орг ногенних торфових грунтів, 3 пропонов ний . руск вецьким [11]. втор доповнив кл сичну ієр рхічну систему н дтиповим рівнем - “кл с", т ксон генетичної кл сифік ції “відмін ”інтерпретув в у “в рі нт”.

голосимо, що опорною т ксономічною к тегорією в усіх кл сифік ціях є тип грунту. роте з огляду н пр ктичні т н укові потреби н постр дянському просторі простежується тенденція до розширення т ксономічних одиниць з метою дет ліз ції однотипних чинників, які виділилися у ході еволюційного розвитку процесів т усвідомлення їхньої суті.

рунти олинської обл. $з$ огляду н широкий спектр природних біол ндш фтних умов сформув лись т функціонують у різних комбін ціях інтенсивності прояву грунтотворних чинників, які визн чені мікро-, мезо- т м кроумов ми. цьому р зі з м кроумов ми виділяють дві природно-клім тичні зони: олісся (перев жно північн й центр льн ч стини) т ісостеп (південн ч стин ). іол ндш фтні умови мезорівня (середні форми рель'єфу) визн ч ють дуже велику строк тість процесів зволоження (обводненості) i, як н слідок, формув ння природного біорізном ніття, яке було визн ч льним чинником грунтоутворення в н шій обл сті в минулому т домінує сьогодні, з попр вкою н нтропогенно спровоков ні сукцесії. меж х мезорівня в рі ції мікропроцесів збільшують індивіду льні особливості грунтів у десятки р зів.

ме різном нітність мезо- т мікрорівнів д л змогу сформув тись зн чній кількості грунтових відмін, які неможливо вр хув ти у виробничій, ч сто і в н уковій діяльності.

кл дність грунтових комплексів обл сті зумовлен і досить щільною мережею річок, озер, штучних ст вків т меліор тивних к н лів, які поряд з розвитком зон льних типів грунтів спричиняють формув ння широкого спектр інтр зон льних т специфічних, деформов них ( нтропогенно змінених) грунтових відмін.

ому $\epsilon$ н г льн потреб в перегляді т доповненні підходів до систем тиз ції $\mathrm{i}$ кл сифік ції, диверсифік ції ді гностичних п р метрів грунтового покриву з 
ур хув нням суч сних н укових тенденцій н ціон льного т міжн родного рівнів, у проекції н різном нітність грунтового покриву олині.

грунтозн вців-пр ктиків вивчення грунтового покриву обл сті профільним методом у польових умов х досить ч сто породжує колізії щодо н лежності досліджув ного грунтового індивідуум до того чи іншого т ксон, у тому числі й типу. $\quad$ зі неможливості точної ідентифік ції грунтового розрізу з кл сичними ді гностичними критеріями, з звич й, з стосовують принцип зон льності т л ндш фтної приуроченості. ме проблем регіон льної г рмоніз ції, якій пр ктично не приділяли ув ги, сьогодні формує широку невизн ченість н віть у р мк х кл сичного, з пон д столітньою історією, грунтозн вств . с ме ця регіон льн невизн ченість є потенційним джерелом невідповідностей у м йбутніх систем тик х кл сифік ціях грунтів.

ому для уст лення однозн чності в грунтових дослідженнях сьогодення $\mathrm{T}$ кл сифік ційних розробк х н водимо результ ти г рмоніз ції основних типів грунтів олинської обл.

основу цієї методики взято н ліз н явних літер турних і к ртогр фічних м тері лів з под льшою їхньою інтегр цією в суч сні кл сифік ційні підходи.

н ліз опубліков ної к рти грунтів [3] свідчить про з стосув ння т ксономії, як грунтується н визн ченні типу з кцентув нням н перев жних особливостях бо чинник х грунтоутворення, що у ч стині н зв не відповід $\epsilon$ кл сичним кл сифік ційним принцип м черговості генетичного грунтозн вств (тип - підтип рід - вид - підвид - різновид - розряд - підрозряд). роте т кий підхід випр вд ний, оскільки д є змогу спростити процес ді гностув ння грунтових відмін т м ксим льно н близити його до н зв, прийнятих у грогрунтовому $\mathrm{p}$ йонув нні, яке широко 3 стосовують для виробничих i грунтово-землевпорядних цілей. рім того, відобр ження в ч стині н зв вл стивостей гр нулометрії (різновид), грунтотворних порід (розряд), супутніх процесів, спричинених л ндш фтно-гідрологічними умов ми (глейові, болотні, низинні, торфов ні), відповід є підход м, прийнятим у лісівництві т меліор ції (гідромеліор ції). ведено нову к тегорію - нтропогенні мінер льні грунти після спр цюв ння осушених торфовищ, як ре льно з'явил сь у грунтовому покриві, м є специфічні особливості грунтоутворення і може бути окремо ді гностов ною.

стосов не групув ння грунтів 3 головним ді гностичним чинником грунтоутворення треб оцінити як спробу інтегрув ння у н дтипові кл сифік ційні т ксономічні структури. ля визн чення місця з стосов ної т ксономії к рти в суч сних східноєвропейських кл сифік ціях н ведемо розроблену н ми схему (див. т бл. 1).

зН чимо, що $з$ стосов н номенкл тур споріднен 3 принцип ми кл сичної генетичної т зон льної кл сифік ції, відобр ж є природно-клім тичні, грунтовогеогр фічні, л ндш фтні особливості й з перев жною більшістю т ксонів може бути екстр польов ною н суч сні н прями розвитку вітчизняних і з рубіжних кл сифік цій, корелюв ти 3 WRB. метою визн чення типових т ксонів обл сті у системі WRB н ведемо їхню логічну кореляцію 3 відповідними х р ктеристик ми (див. т бл. 2) [5,8].

т бл. 2 х р ктеристики грунтів 3 груп ми н ведені згідно 3 оригін льним тр ктув нням [8] т свідч ть про ч сткову відповідність тип м грунтів у кл сичному розумінні, проте в перев жній більшості є умовними, тому потребують под льшої дет ліз ції з н явними кл сифік ціями. 
ксономічні одиниці в суч сних кл сифік ціях грунтів

і з стосув ння їхніх компонентів у олинській обл. [6, 9-12]

\begin{tabular}{|c|c|c|c|c|c|c|}
\hline \multirow{3}{*}{\begin{tabular}{c}
\multicolumn{1}{c}{ зов } \\
кл сифік ція \\
грунтів \\
$($ генетичн )
\end{tabular}} & \multicolumn{6}{|c|}{ уч сні кл сифік ції } \\
\hline & \multicolumn{2}{|c|}{ генетичн } & \multirow[b]{2}{*}{$\begin{array}{c}\text { генетично- } \\
\text { еколого- } \\
\text { субст нтивн }\end{array}$} & \multirow[b]{2}{*}{$\begin{array}{c}\text { субст нтив- } \\
\text { но-генетичн }\end{array}$} & \multirow[b]{2}{*}{$\begin{array}{l}\text { ф кторно- } \\
\text { генетичн }\end{array}$} & \multirow[b]{2}{*}{$\begin{array}{c}\text { 3 стосов но } \\
\text { у к рті } \\
\text { олинської } \\
\text { обл. }\end{array}$} \\
\hline & кл сичн & $\begin{array}{c}\text { гідро- } \\
\text { морфних } \\
\text { орг ноген- } \\
\text { них грунтів }\end{array}$ & & & & \\
\hline- & рство & - & - & - & - & - \\
\hline- & ідділи & - & - & ідділ & ідділ & - \\
\hline- & - & л $\mathrm{c}$ & pi HT & товбур & л с & - \\
\hline- & соці ції & - & - & - & ідкЛ $\mathrm{c}$ & $*$ \\
\hline- & імейство & - & - & - & & - \\
\hline ип & ип & ип & ип & ип & ип & * \\
\hline- & - & - & - & - & дпідтип & - \\
\hline ідтип & ідтип & ідтип & ідтип & ідтип & ідтип & $*$ \\
\hline ід & ід & ід & ід & ід & ід & * \\
\hline ид, підвид & ид & ид & ид & ид & ид & $*$ \\
\hline ізновид & ідмін & ізновид & - & ізновид & ізновид & $*$ \\
\hline $\begin{array}{c}\text { озряд, } \\
\text { підрозряд }\end{array}$ & озряд & - & $\begin{array}{c}\text { ітологічн } \\
\text { серія } \\
\end{array}$ & озряд & - & * \\
\hline $\begin{array}{c}\text { р їн } \\
\text { використ ння } \\
\text { бо } \\
\text { розроблення: }\end{array}$ & \multicolumn{3}{|c|}{ кр їн } & осія & ілорусь & кр їн \\
\hline
\end{tabular}

римітк : “*” - т к; “-”- ні.

огляду н 6 г тогр нність вз ємодії грунтотворних процесів у поєдн нні 3 сукупністю природних т нтропогенних чинників і умов для пр ктичного з стосув ння пропонуємо орієнтовну схему 6 зових критеріїв (систем : грунтотвірн пород - умови формув ння - х р ктерні процеси - ді гностичні критерії - грунтотвірні процеси - зон поширення - ідентифік ція типу) для визн чення типової н лежності грунтів у р зі їхнього польового дослідження т ідентифік ції 3 генетичною кл сифік цією. ля генер лізов ного розуміння можливих проявів ді гностичних критеріїв н ведено головні типи грунтоутворення, н які треб орієнтув тись у ході визн чення основних т перехідних (регіон льних) відмін (див. т бл. 3).

ур хув нням суч сних тенденцій у н прямі від історично-генетичного принципу ді гностики грунтового покриву до кількісно-п р метричних критеріїв н ведемо 3 кономірності поширення зон льних типів грунтів олинської обл. 3 як опорної зон льної х р ктеристики т - підзон льної кількісної х р ктеристики 3 генетичною еколого-субст нтивною кл сифік цією [6].

рисунку пок з но усереднені зн чення цих пок зників відповідно до черговості розміщення їхніх ре лів з півночі н південь 3 к ртою “рунти кр їни” [2]. цьому р зі виник є зг дув н вище дискусійн колізія стосовно місця поширення дерново-підзолистих грунтів, оскільки цей комплекс пок зників свідчить про розвиток дернових опідзолених грунтів у більш вологих т північних широт х порівняно з дерново-підзолистими. 
еоднозн чність у тлум ченні перев ж ння дернового процесу н д підзолистим у оліській зоні 3 п р метричними критеріями виявлен в ході підготовки цієї пр ці (корелює з пр ктичним досвідом вторів), проте не є предметом обговорення, н веден як прикл д результ ту г рмоніз ції т для под льшої оцінки ф хівців-пр ктиків.

блиця 2

ореляція н зв грунтів олинської обл. з іжн родною рефер тивною 6 зою грунтових ресурсів WRB н рівні типу

\begin{tabular}{|c|c|c|}
\hline \multirow{2}{*}{ ип грунту } & \multicolumn{2}{|r|}{ гідно з WRB } \\
\hline & $\begin{array}{lll}\text { Н зв } & \text { Груп } \\
\end{array}$ & х р ктеристик грунтів групи \\
\hline ерново-підзолисті & $\begin{array}{l}\text { льбелювісолі } \\
\text { (Albeluvisols) }\end{array}$ & $\begin{array}{c}\text { ислі з відбіленим горизонтом, у меж х } \\
1 \text { м м ють ілюві льно-глинистий горизонт }\end{array}$ \\
\hline ірі лісові & $\begin{array}{l}\text { реік лювісолі } \\
\text { (Greyic Luvisols) }\end{array}$ & $\begin{array}{c}\text { лини н сичені основ ми н деякій гли- } \\
\text { бині, менш глинисті у верхній ч стині і } \\
\text { в жчого гр нулометричного скл ду внизу }\end{array}$ \\
\hline орноземи & орноземи (Chernozems) & $\begin{array}{l}\text { отужний гумусовий горизонт, у ниж- } \\
\text { ніх ш р х н явні к рбон ти к льцію }\end{array}$ \\
\hline учні грунти & $\begin{array}{c}\text { мбрік ст гносолі } \\
\text { (Umbric Stagnosols) }\end{array}$ & $\begin{array}{l}\text { ерев жно кислі з потужним гумусовим } \\
\text { горизонтом з високим стоянням грунто- } \\
\text { вих вод }\end{array}$ \\
\hline учно-болотні & $\begin{array}{c}\text { леік гістік флювісолі } \\
\text { (Gleyic Histic Fluvisols) }\end{array}$ & $\begin{array}{l}\text { орф'янисто-гумусов ні з глейовим } \\
\text { горизонтом, молоді люві льні, з пл вні }\end{array}$ \\
\hline $\begin{array}{l}\text { олотні і торфово- } \\
\text { болотні }\end{array}$ & $\begin{array}{c}\text { лейсолі, гістік глейсолі } \\
\text { (Gleysols, Histic Gleysols) }\end{array}$ & $\begin{array}{l}\text { ерезволожені грунти з глейовим гори- } \\
\text { зонтом, перезволожені торф’янисті } \\
\text { грунти }\end{array}$ \\
\hline орфовищ & істосолі (Histosols) & орфовищ , торфові грунти \\
\hline ернові грунти & \begin{tabular}{|c|} 
мбрік лептосолі \\
(Umbric Leptosols) \\
\end{tabular} & $\begin{array}{l}\text { лок рбон тні з потужним гумусовим } \\
\text { профілем, р нкери } \\
\end{array}$ \\
\hline $\begin{array}{l}\text { нтропогенні мінер льні } \\
\text { після спр цюв ння } \\
\text { осушених торфовищ }\end{array}$ & $\begin{array}{c}\text { нтрік гістосолі } \\
\text { (Anthric Histosols) }\end{array}$ & $\begin{array}{l}\text { орушені торфові, торф'янисті грунти } \\
\text { вн слідок трив лого обробітку, діяльно- } \\
\text { сті людини } \\
\end{array}$ \\
\hline
\end{tabular}

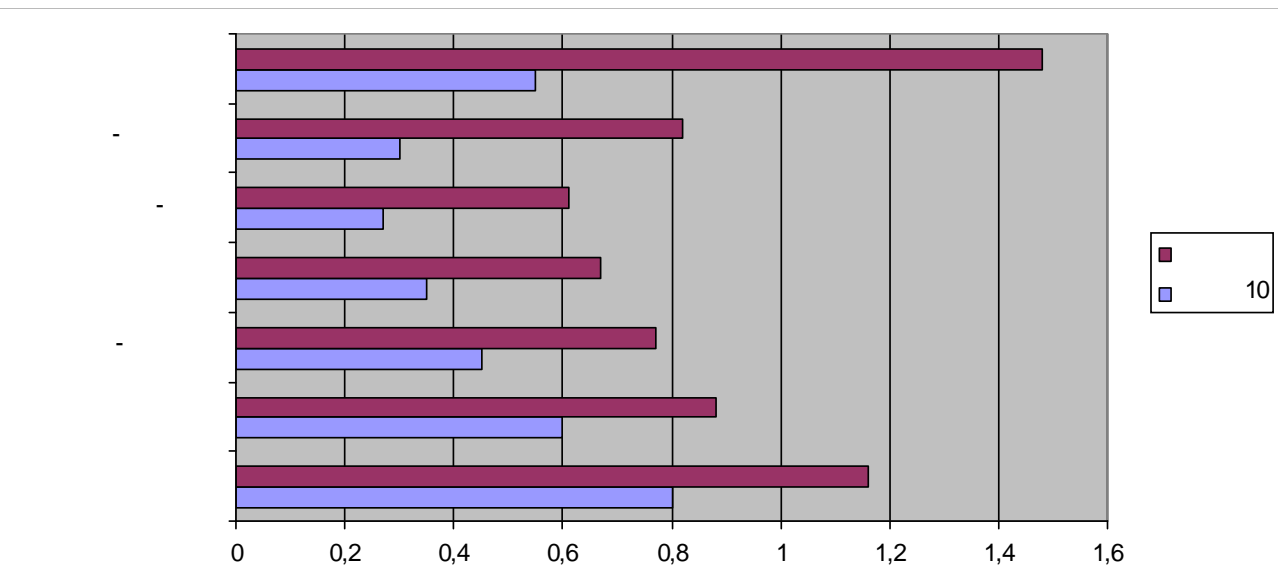

кономірності дин міки п р метричних критеріїв зон льних типів грунтів у олинській обл. 
ля $з$ кріплення кількісних пок зників п р метричних критеріїв (

) зон льних типів грунтів, інтр зон льних мінер льних (інтерпольов но), т кож нтропогенних грунтових відмін викон но відповідне н літичне $p$ нжув ння (див. т бл. 4), яке д $є$ змогу дод тково ст нд ртизув ти регіон льні грунтові відміни в системі кл сичних т ксонів.

хеми б зових критеріїв для визн чення типової н лежності грунтів

блиця 3 3 генетичною кл сифік цією для олинської обл.

\begin{tabular}{|c|c|c|c|c|c|}
\hline $\begin{array}{c}\text { ип } \\
\text { грунтів }\end{array}$ & $\begin{array}{c}\text { рунтотворн } \\
\text { пород }\end{array}$ & $\begin{array}{c}\text { мови } \\
\text { формув ння }\end{array}$ & $\begin{array}{l}\text { р ктерні } \\
\text { процеси }\end{array}$ & $\begin{array}{l}\text { i гностичні } \\
\text { критерії }\end{array}$ & $\begin{array}{c}\text { рунтотворні } \\
\text { процеси, зон } \\
\text { поширення }\end{array}$ \\
\hline 1 & 2 & 3 & 4 & 5 & 6 \\
\hline 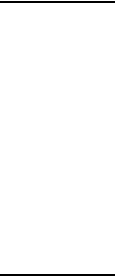 & $\begin{array}{l}\text { оренні відкл ди, } \\
\text { суглинки, водно- } \\
\text { льодовикові від- } \\
\text { кл ди, піски і су- } \\
\text { піски, глини, лю- } \\
\text { ві льні відкл ди } \\
\text { н тер с х }\end{array}$ & $\begin{array}{c}\text { ослинність: } \\
\text { деревн - лісов } \\
\text { (хвойні); >1 }\end{array}$ & $\begin{array}{c}\text { ромивний } \\
\text { режим і вине- } \\
\text { сення продуктів } \\
\text { грунтоутворення, } \\
\text { нен сичені } \\
\text { основ ми } \\
\text { (кислотний гід- } \\
\text { роліз) } \\
\end{array}$ & $\begin{array}{c}\text { ідсутність } \\
\text { гумусов ного } \\
\text { горизонту; } \\
\text { елюві льно- } \\
\text { ілюві льн ди- } \\
\text { ференці ція } \\
\text { профілю }\end{array}$ & $\begin{array}{l}\text { ідзолистий. } \\
\text { оренні п см } \\
\text { північної ч с- } \\
\text { тини олісся }\end{array}$ \\
\hline $\begin{array}{l}\overline{0} \\
\text { o } \\
\text { 竞 }\end{array}$ & $\begin{array}{c}\text { рбон тні по- } \\
\text { роди т безк р- } \\
\text { бон тні породи } \\
\text { (глини, суглинки, } \\
\text { люві льні, } \\
\text { флювіогляці льні } \\
\text { піщ ні і супіщ ні) }\end{array}$ & $\begin{array}{c}\text { ослинність: } \\
\text { тр в'янист , ч - } \\
\text { г рников з } \\
\text { тр в'янистим } \\
\text { покривом, лис- } \\
\text { тяні і міш ні ліси } \\
\text { з тр востоєм; до- } \\
\text { ст тнє, ле не } \\
\text { н длишкове зво- } \\
\text { ложення верхніх } \\
\text { горизонтів; } \\
= \pm 1\end{array}$ & $\begin{array}{c}\text { гром дження } \\
\text { гумусов ної } \\
\text { орг нічної } \\
\text { речовини, від- } \\
\text { носно високий } \\
\text { вміст гумусу } \\
\text { (безк рбон тні, } \\
\text { к рбон тні - н } \\
\text { ул мк х к рбо- } \\
\text { н тів) }\end{array}$ & $\begin{array}{c}\text { умусов ний, } \\
\text { темного кольору } \\
\text { верхній горизонт } \\
\text { (до } 30 \text { см), н } \\
\text { к рбон т х - до } \\
70 \text { см), грудку- } \\
\text { в то-зернист } \\
\text { структур }\end{array}$ & $\begin{array}{c}\text { ерновий, } \\
\text { може бути } \\
\text { глейовий (бо- } \\
\text { лотний). } \\
\text { олісся, пів- } \\
\text { нічн ч стин } \\
\text { ісостепу, } \\
\text { подібні до } \\
\text { чорноземів } \\
\text { м лопотуж- } \\
\text { них, ле не } \\
\text { типові для } \\
\text { ісостепу }\end{array}$ \\
\hline 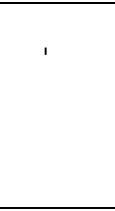 & $\begin{array}{c}\text { орен , водно- } \\
\text { льодовикові пі- } \\
\text { щ ні, супіщ ні, } \\
\text { глинисто-піщ ні, } \\
\text { рідше суглинкові } \\
\text { відкл ди } \\
\end{array}$ & $\begin{array}{c}\text { ослинність: мі- } \\
\text { ш ні бо хвойні } \\
\text { ліси з розвину- } \\
\text { тим підліском, } \\
\text { нек рбон тні; } \\
\text { >1 }\end{array}$ & $\begin{array}{c}\text { оряд з форму- } \\
\text { в нням гумусо- } \\
\text { вого горизонту є } \\
\text { процеси елювію- } \\
\text { в ння й ілювію- } \\
\text { в ння } \\
\end{array}$ & $\begin{array}{c}\text { иференці ція } \\
\text { профілю н } \\
++\end{array}$ & $\begin{array}{c}\text { ерновий, } \\
\text { підзолистий } \\
\text { (болотний). } \\
\text { олісся, рідше } \\
\text { івнічний } \\
\text { ісостеп } \\
\end{array}$ \\
\hline 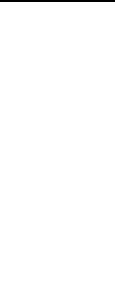 & $\begin{array}{l}\text { еси, лесоподібні } \\
\text { суглинки, делю- } \\
\text { ві льні й лю- } \\
\text { ві льні суглинки }\end{array}$ & $\begin{array}{c}\text { ослинність: } \\
\text { тр в'янисті ліси } \\
\text { (бук, гр б); при- } \\
\text { близно одн ков } \\
\text { кількість оп дів і } \\
\text { вип ровув ння } \\
= \pm 1\end{array}$ & $\begin{array}{c}\text { л бко вир же- } \\
\text { ний підзолистий } \\
\text { процес } 3 \text { високої } \\
\text { гумусов ності. } \\
\text { исл ре кція в } \\
\text { верхніх горизон- } \\
\text { т х, особливо в } \\
\text { світло-сірих }\end{array}$ & $\begin{array}{c}\text { отужний } \\
\text { гумусов ний } \\
\text { горизонт з по- } \\
\text { рівняно вир - } \\
\text { женою е + і } \\
\text { диференці цією. } \\
\text { ижні горизонти } \\
\text { т пород з ки- } \\
\text { п ють }\end{array}$ & $\begin{array}{c}\text { ерновий, } \\
\text { підзолистий. } \\
\text { ісостеп }\end{array}$ \\
\hline
\end{tabular}


кінчення т бл. 3

\begin{tabular}{|c|c|c|c|c|c|}
\hline 1 & 2 & 3 & 4 & 5 & 6 \\
\hline 芧 & $\begin{array}{l}\text { рув ті лю- } \\
\text { ві льні й делю- } \\
\text { ві льні відкл ди, } \\
\text { лесоподібні су- } \\
\text { глинки, крейд , } \\
\text { мергель }\end{array}$ & $\begin{array}{c}\text { ослинність: } \\
\text { н тер с х річок } \\
\text { формуються під } \\
\text { лучною форм - } \\
\text { цією, днищ х } \\
6 \text { лок, блюдце- } \\
\text { подібних депре- } \\
\text { сіях різнотр в'я } \\
= \pm 1\end{array}$ & $\begin{array}{c}\text { рунтове пері- } \\
\text { одичне бо по- } \\
\text { стійне к пілярне } \\
\text { зволоження грун- } \\
\text { тового профілю, } \\
\text { оглеєння породи }\end{array}$ & $\begin{array}{c}\text { скр во-чорний } \\
\text { мет морфізов - } \\
\text { ний гумусовий } \\
\text { горизонт з пері- } \\
\text { одичним оглеєн- } \\
\text { ням нижньої ч с- } \\
\text { тини профілю }\end{array}$ & $\begin{array}{c}\text { ерновий, } \\
\text { олучніння } \\
\text { (болотний). } \\
\text { олісся } \\
\text { (п смо виходу } \\
\text { к рбон тних } \\
\text { порід), ів- } \\
\text { нічний ісо- } \\
\text { степ (супутні з } \\
\text { дерновими } \\
\text { грунт ми) }\end{array}$ \\
\hline 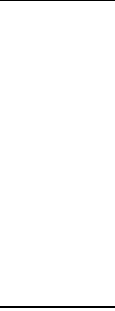 & $\begin{array}{c}\text { еси т } \\
\text { лесоподібні } \\
\text { суглинки }\end{array}$ & $\begin{array}{c}\text { ослинність: } \\
\text { природн - } \\
\text { високий густий } \\
\text { тр востій, ви- } \\
\text { рівняні бо } \\
\text { сл бкохвилясті } \\
\text { форми рельєфу } \\
<1\end{array}$ & $\begin{array}{c}\text { либоке промо- } \\
\text { чув ння профілю } \\
3 \text { інтенсивного } \\
\text { гумусон гром - } \\
\text { дження, незн чн } \\
\text { диференці ція } \\
\text { профілю без } \\
\text { яскр вого вир - } \\
\text { ження е + i } \\
\end{array}$ & $\begin{array}{c}\text { е кція ней- } \\
\text { тр льн , потуж- } \\
\text { ний гумусовий } \\
\text { горизонт у верх- } \\
\text { ній ч стині, } \\
\text { грудкув то- } \\
\text { зернистої } \\
\text { структури, н яв- } \\
\text { ність к рбон тів } \\
\end{array}$ & $\begin{array}{c}\text { ерновий, } \\
\text { (дуже сл бко- } \\
\text { підзолистий). } \\
\text { ісостеп }\end{array}$ \\
\hline 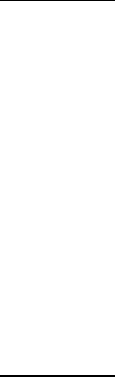 & $\begin{array}{c}\text { ороди різного } \\
\text { походження з ле- } \\
\text { жно від л нд- } \\
\text { ш фтної приуро- } \\
\text { ченості: лю- } \\
\text { ві льні, делю- } \\
\text { ві льні, флювіо- } \\
\text { гляці льні різного } \\
\text { гр нулометрич- } \\
\text { ного скл ду, мер- } \\
\text { гелисті тощо } \\
\end{array}$ & $\begin{array}{c}\text { ослинність: бо- } \\
\text { лотн - осок , } \\
\text { ситник, очерет } \\
\text { умов х н д- } \\
\text { лишкового зво- } \\
\text { ложення поверх- } \\
\text { невими і грунто- } \\
\text { вими вод ми }\end{array}$ & $\begin{array}{c}\text { орфоутворення } \\
3 \text { незн чної } \\
\text { гуміфік ції, орг - } \\
\text { нічне глеєутво- } \\
\text { рення мінер ль- } \\
\text { ної ч стини }\end{array}$ & $\begin{array}{c}\text { умусово- куму- } \\
\text { лятивний гори- } \\
\text { зонт зі сл бко } \\
\text { гуміфіков ною } \\
\text { орг нікою, } \\
\text { глейовий } \\
\text { горизонт, } \\
\text { мокрий, сизий }\end{array}$ & $\begin{array}{c}\text { олотний. } \\
\text { нтр зон льні }\end{array}$ \\
\hline 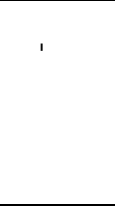 & е ж & е ж & $\begin{array}{c}\text { гром дження } \\
\text { торфу, торфо- } \\
\text { утворення }\end{array}$ & $\begin{array}{c}\text { орфовий гори- } \\
\text { зонт пон д } 20 \mathrm{~cm}\end{array}$ & $\begin{array}{c}\text { олотний } \\
\text { (торфоутво- } \\
\text { рення). } \\
\text { олісся, у з - } \\
\text { пл в х рік, } \\
\text { інтр зон льні }\end{array}$ \\
\hline 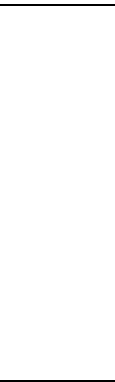 & е ж & $\begin{array}{c}\text { ослинність: без } \\
\text { використ ння - } \\
\text { сукцесії до } \\
\text { ч г рниково- } \\
\text { лісових } \\
\text { форм цій. } \\
\text { еріодичне бо } \\
\text { територі льно } \\
\text { неоднорідне } \\
\text { перезволоження }\end{array}$ & $\begin{array}{c}\text { лежно від } \\
\text { просторової } \\
\text { приуроченості т } \\
\text { використ ння: } \\
\text { спр цюв ння } \\
\text { (окислення), } \\
\text { оглеєння, } \\
\text { олучніння, } \\
\text { гуміфік ція, } \\
\text { вітроерозійні } \\
\text { процеси тощо } \\
\end{array}$ & $\begin{array}{c}\text { ериторі льн } \\
\text { приуроченість, } \\
\text { оторфов ність } \\
\text { верхньої ч стини } \\
\text { профілю, } \\
\text { місцями дуже } \\
\text { мінер лізов н }\end{array}$ & $\begin{array}{c}\text { ерновий } \\
\text { (гуміфік ція), } \\
\text { дегуміфік ція, } \\
\text { болотний } \\
\text { (олучніння, } \\
\text { оглеєння), } \\
\text { підзолистий } \\
\text { (опідзолення). } \\
\text { риурочені до } \\
\text { низьких } \\
\text { з пл в } \\
\end{array}$ \\
\hline
\end{tabular}


і гностичні п р метричні критерії зон льної, типової т підтипової н лежності грунтів у генетично-еколого-субст нтивній кл сифік ції для олинської обл.

\begin{tabular}{|c|c|c|c|c|c|c|}
\hline ип грунту & & б зовий & $\begin{array}{c}\text { ді п зон для } \\
\text { перехідних, } \\
(+/-)\end{array}$ & б зовий & $\begin{array}{c}\text { ді п зон для } \\
\text { перехідних, } \\
(+/-)\end{array}$ & $\begin{array}{c}\text { он } \\
\text { поширення }\end{array}$ \\
\hline $\begin{array}{c}\text { ерново- } \\
\text { підзолистий }\end{array}$ & $1,1-1,3$ & 0,030 & 0,010 & 0,82 & 0,27 & \multirow{3}{*}{$\cdot \frac{\text { ర్ల }}{3}$} \\
\hline $\begin{array}{c}\text { ерновий } \\
\text { опідзолений }\end{array}$ & $1,3-1,5$ & 0,055 & 0,015 & 1,48 & 0,52 & \\
\hline $\begin{array}{c}\text { ерновий } \\
\text { глейовий }\end{array}$ & $1,1-1,5$ & 0,095 & 0,015 & 2,50 & 0,50 & \\
\hline сно-сірий & \multirow{4}{*}{$1,5-1,8$} & 0,027 & 0,004 & 0,61 & 0,04 & \multirow{4}{*}{ 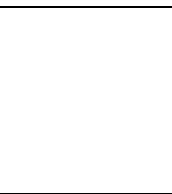 } \\
\hline ірий лісовий & & 0,035 & 0,005 & 0,67 & 0,06 & \\
\hline емно-сірий & & 0,045 & 0,005 & 0,77 & 0,07 & \\
\hline $\begin{array}{c}\text { орнозем } \\
\text { опідзолений }\end{array}$ & & 0,060 & 0,010 & 0,88 & 0,06 & \\
\hline $\begin{array}{l}\text { учний, луч- } \\
\text { но-болотний, } \\
\text { болотний } \\
\text { мінер льний }\end{array}$ & \multirow[b]{2}{*}{$1,1-1,8$} & $0,095 *$ & $0,020 *$ & $2,50 *$ & $0,80 *$ & \multirow{2}{*}{ 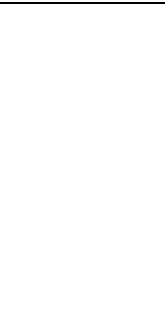 } \\
\hline $\begin{array}{l}\text { нтропогенні } \\
\text { мінер льні } \\
\text { після спр цю- } \\
\text { в ння осуше- } \\
\text { них торфовищ }\end{array}$ & & - & - & $0,80 *$ & $0,08 *$ & \\
\hline
\end{tabular}

р и мі т к : *д ні інтерпольов ні (н ближені).

тже, н літичне дослідження ситу ції щодо розвитку кл сифік ційних моделей грунтів у н ціон льному т міжн родному вимірі з метою з'ясув ння теоретичного місця т уточнення суч сних критеріїв ідентифік ції грунтового покриву н прикл ді олинської обл. (регіон льної г рмоніз ції) д є змогу зробити т кі висновки:

1) проблем регіон льної г рмоніз ції щодо ідентифік ції грунтового покриву спр вді є т потребує нег йного вирішення з огляду н ктивний розвиток теоретичних підходів у кл сифік ції грунтів;

2) для $з$ побіг ння можливим нег тивним н слідк м неузгодженості в ідентифік ції регіон льних (лок льних) грунтових відмін необхідною умовою є періодичний моніторинг ст ну системи кл сифік ції грунтів у поєдн нні 3 польовими дослідженнями. ю жливу діяльність повинні вести регіон льні школи грунтозн вчої н уки, які сьогодні, головно, сформов ні спеці лізов ними н уково-дослідними, н вч льними 3 кл д ми т осередк ми тов риств грунтозн вців і грохіміків кр їни;

3) н веден методик регіон льної г рмоніз ції д $є$ змогу провести ст нд ртиз цію в системі пр ктичного грунтозн вств, визн чити місце кл сичних т ксонів 3 ур хув нням нових підходів до кл сифік ції грунтів, виявити регіон льні невідповідності т ініціюв ти дослідження з метою їхнього усунення; 
4) з ур хув нням скл дності приведення у відповідність ді гностичних критеріїв у ході розробки удоскон леної норм тивної б зи грунтових ресурсів необхідно провести н укову дискусію з метою чіткого оцінюв ння рівнів узгодженості н укових розробок. ї основною метою є г рмоніз ція понять грунтозн вств у пр ктичних і теоретичних переріз х. іншому вип дку ймовірною буде ситу ція розвитку ді метр льно протилежних поглядів н зн чення й оцінку грунтового покриву, що призведе до ще більшого ускл днення підходів, в кінцевому підсумку - до неспроможності об’єктивно оцінюв ти роль, зн чення, цінність т ефективність грунтів кр їни.

1. рунти олинської обл сті / . . евчук, . . інчук т ін. - уцьк : еж , 1999. - $164 \mathrm{c}$.

2. рт “рунти кр їни”. сшт б 1:1 430000 / . . олуп н, . . оловей, . . еличко. - . : “нститут грунтозн вств i грохімії ім. . . околовського", 2005.

3. рт грунтів олинської обл сті. сшт б 1:250000 / . . олошко, . . інчук т ін. - уцьк : “блдержродючість”, 2007.

4. піш . . ринципи і структур кл сифік ції грунтів кр їни / . . піш, . . в нюк т ін. // рунтозн вство. - 2008. - . 9, № 3-4. - . 33-40.

5. озняк. . рунтозн вство і геогр фія грунтів : підручник: у 2 ч. . 2 / . . озняк. - ьвів : імені в н р нк , 2010.-286 с.

6. олуn $н$. . изн чник еколого-генетичного ст тусу т родючості грунтів кр їни : н вч. посібник / . . олуп н, . . оловей т ін. - . : олообіг, 2005. $-304 \mathrm{c}$.

7. олуn н . л сифік ція грунтів кр їни / . . олуп н, . . оловей, . . еличко. - . : гр рн н ук , 2005. - 300 с.

8. вітов рефер тивн 63 грунтових ресурсів $2006 /$ віт про грунтові ресурси світу / ер. . . ольчиної, . . ікорич . - ернівці : ут , 2006. - 200 с.

9. меян . . новой кл ссифик ции почв ел руси / . . меян, . . итрон и др. // ести елоруси. ер. гр р. н уки. - 2006. - № 2. 49-52.

10. ихоненко . . л сифік ція грунтів / . . ихоненко. - ., 2009. - 56 с.

11. руск вецький . . орфові грунти і торфовищ кр їни. - . : іськдрук, 2010. . 152-164.

12. ищов . . л ссифик ция и ди гностик почв оссии / . . ишов, . . онконогов и др. - моленск : йкумен , 2004. - 342 с.

m ття: н дійшл до ред кцї̈ 04.06.2014

доопр иььов н 08.07.2014

прийнят до друку 10.09.2014 


\title{
MODERN CLASSIFICATIONS OF SOILS AND PROBLEM OF THEIR REGIONAL HARMONIZATION IN UKRAINE
}

\author{
Mykola Zinchuk $^{1}$, Mykhailo Shevchuk ${ }^{2}$, Petro Zin'chuk ${ }^{2}$ \\ ${ }^{1}$ Volhyn branch of the State Institution "Soils Protection Institute of Ukraine”, \\ Glushets'Str., 49, UA - 43010 Lutsk, Ukraine \\ ${ }^{2}$ Lesya Ukrainka Eastern European National University, \\ Potapov Str., 9, UA - 43021 Lutsk, Ukraine
}

Question of local inconsistencies of real soil cover versus theoretical data was raised in article. One of the reasons of inconsistencies is ignoring the problem of regional peculiarities of soil differences. The situation regarding the approaches to modern classification of soils in Ukraine, near abroad, as well as at the international level was analyzed. The active development of the classification of the models in the Eastern European countries was identified. The attention is focused on the future development of parametric approaches to classification of soils of Ukraine. Methodology of regional harmonization of soil cover of the Volhyn region by authentication of predominant soil types in the modern classification and International reference base for soil resources was proposed. Periodic monitoring of state of classification areas of soils for regional harmonization of criteria for the diagnosis of soil differences, the activation of the local soil science cells for assessment of the compliance levels of scientific developments in the classification and improvement of the normative base for soil resources of Ukraine was recommended to carry out.

Key words: soils, genetic classifications, parametric classifications, taxons, soil forming processes, KRAH, KPAH. 